\title{
Antifungal activity against Alternaria solani and control of early blight in tomato by essential oil of bergamot orange
}

\section{Atividade antifúngica contra Alternaria solani e controle da pinta preta do tomateiro por óleo essencial de bergamota}

\author{
Camila Hendges ${ }^{1 *}$; José Renato Stangarlin²; Márcia de Holanda Nozaki³; Eloisa \\ Lorenzetti'; Odair José Kuhn²
}

\begin{abstract}
Highlights:
Bergamot essential oil is toxic to the fungus Alternaria solani.

The mycelial growth of $A$. solani was reduced by $68 \%$ and sporulation by $29 \%$.

The antifungal effect on the mycelial growth of the fungus depends on the dose of essential oil.

In the treated leaves, the area under progress curve of the early blight was reduced by $21 \%$.

Bergamot oil activates defense enzymes in tomato inoculated with $A$. solani.
\end{abstract}

\begin{abstract}
The early blight (caused by the fungus Alternaria solani) results in significant damage to the tomato crop, directly affecting productivity. An alternative to the frequent use of pesticides is the use of essential oils, which can act in defense against phytopathogens. The objective of this work was to evaluate the toxic activity in vitro of the bergamot orange (Citrus aurantium ssp. bergamia) essential oil against $A$. solani, the control of the early blight, and the activity of defense enzymes in tomatoes treated with this oil and inoculated with $A$. solani. Mycelial discs of $A$. solani were added to dishes with V8 culture media to which essential oil at concentrations of $0,500,1000,1500,2000$, and $2500 \mu \mathrm{L} \mathrm{L}^{-1}$, in addition to a standard fungicide treatment (azoxystrobin + difenoconazole, $200+125 \mathrm{~g} \mathrm{~L}^{-1}$, respectively) was added. The Petri dishes were incubated at $25^{\circ} \mathrm{C}$ in the dark. Mycelial growth was evaluated daily for 19 days, when all treatments reached maximum growth. Sporulation analysis was performed thereafter. Tomato plants were treated with bergamot essential oil, 30 days after transplanting, in the concentrations and fungicide mentioned, in the second pair of leaves. After 72 hours, the pathogen was inoculated using a spray bottle, on treated leaves (second pair of leaves) and untreated leaves (third pair of leaves). The area under the disease progress curve (AUDPC) was calculated based on five severity assessments. The activity of peroxidase (POX), polyphenol oxidase (PPO), and phenylalanine ammonia-lyase (PAL) was evaluated in leaves treated with the concentration of $2500 \mu \mathrm{L} \mathrm{L}^{-1}$ of essential oil. The concentration of $2500 \mu \mathrm{L} \mathrm{L}^{-1}$ reduced mycelial growth and sporulation of the pathogen by $68.15 \%$ and $29.48 \%$, respectively. In treatments with application of essential oil, lower AUDPC was observed for a concentration of $2500 \mu \mathrm{L} \mathrm{L}^{-1}$, which was statistically similar to that observed for fungicide application, both in treated and untreated leaves. A greater activity of PPO, POX, and PAL was found locally and systemically, both in the second and third leaves, at concentration of $2500 \mu \mathrm{L} \mathrm{L}^{-1}$. The essential oil of bergamot can be an alternative for the control of early blight in tomato.
\end{abstract}

Key words: Citrus aurantium. Alternative control. Resistance induction.

1 Discente do Curso de Doutorado do Programa de Pós-Graduação em Agronomia, Universidade Estadual do Oeste do Paraná, UNIOESTE, Marechal Cândido Rondon, PR, Brasil. E-mail: hendgescamila@hotmail.com

2 Profs. Drs., Programa de Pós-Graduação em Agronomia, UNIOESTE, Marechal Cândido Rondon, PR, Brasil. E-mail: jose. stangarlin@unioeste.br; ojkuhn@gmail.com

3 Prof $^{\mathrm{a}}$ Dr ${ }^{\mathrm{a}}$, Pontifícia Universidade Católica do Paraná, PUCPR, Toledo, PR, Brasil. E-mail: marcia.nozaki@hotmail.com

$4 \mathrm{Dr}^{\mathrm{a}}$ Eng $^{\mathrm{a}} \mathrm{Agr}^{\mathrm{a}}$, UNIOESTE, Marechal Cândido Rondon, PR, Brasil. E-mail: eloisa-lorenzetti@hotmail.com

* Author for correspondence

Received: May 09, 2019 - Approved: June 01, 2020

Semina: Ciências Agrárias, Londrina, v. 41, n. 5, suplemento 1, p. 1861 -1874, 2020 


\section{Resumo}

A pinta preta (causada pelo fungo Alternaria solani) causa prejuízos significativos na cultura do tomateiro, afetando diretamente a produtividade. Uma alternativa ao uso frequente de agrotóxico é a utilização de óleos essenciais, que podem atuar na defesa contra fitopatógenos. O objetivo deste trabalho foi avaliar a atividade tóxica in vitro do óleo essencial de bergamota (Citrus aurantium subsp. bergamia) contra A. solani, o controle da pinta preta e a atividade de enzimas de defesa em tomateiros tratados com esse óleo e inoculados com A. solani. Discos miceliais de $A$. solani foram adicionados em placas com meio de cultura V8 adicionado de óleo essencial nas concentrações de 0, 500, 1000, 1500, 2000 e $2500 \mu \mathrm{L} \mathrm{L}^{-1}$, além de um tratamento padrão com fungicida (azoxistrobina + difenoconazol, $200+125$ $\mathrm{g} \mathrm{L}^{-1}$ respectivamente). As placas de Petri foram incubadas a $25^{\circ} \mathrm{C}$ no escuro. $\mathrm{O}$ crescimento micelial foi avaliado diariamente, por 19 dias, quando todos os tratamentos atingiram o máximo crescimento, sendo então feita a análise da esporulação. Aos 30 dias após o transplantio, o segundo par de folhas de plantas de tomate foram tratadas com óleo essencial de bergamota e de fungicida nas concentrações de óleo citados. Após 72 horas o patógeno foi inoculado com borrifador, nas folhas tratadas (segundo par de folhas) e nas não tratadas (terceiro par de folhas). A área abaixo da curva de progresso da doença (AACPD) foi calculada com base em cinco avaliações de severidade. A atividade de peroxidase (POX), polifenoloxidase (PPO) e fenilalaninaamônia-liase (PAL) foi avaliada em folhas tratadas com a concentração de $2500 \mu \mathrm{L} \mathrm{L}^{-1}$ de óleo essencial. A concentração de $2500 \mu \mathrm{L} \mathrm{L}^{-1}$ reduziu o crescimento micelial e a esporulação do patógeno, em $68,15 \%$ e $29,48 \%$, respectivamente. Nos tratamentos com aplicação de óleo essencial, a menor AACPD foi observada para a concentração de $2500 \mu \mathrm{L} \mathrm{L}^{-1}$, sendo semelhante estatisticamente ao observado para a aplicação de fungicida, tanto nas folhas tratadas quanto nas não tratadas. Foi constatada uma maior atividade de PPO, POX e PAL de maneira local e sistêmica, tanto no $2^{\circ}$ quanto no $3^{\circ}$ par de folhas, na concentração de $2500 \mu \mathrm{L} \mathrm{L}^{-1}$. O óleo essencial de bergamota pode ser uma alternativa no controle da pinta preta do tomateiro.

Palavras-chave: Citrus aurantium. Controle alternativo. Indução de resistência.

\section{Introduction}

Tomato (Solanum lycopersicum L.) has economic and food value and is of great social importance. It generates direct and indirect jobs as it requires a large amount of labor from its cultivation to its commercialization (Instituto Capixaba de Pesquisa, Assistência Técnica e Extensão Rural [INCAPER], 2010).

Tomato is one of the cultivated species most prone to diseases, which cause significant losses in production. Early blight, also known as alternaria black spot, which is caused by the fungus Alternaria solani, is one of the most frequent leaf diseases occurring in all regions where vegetables are grown (Filgueira, 2008). This pathogen is highly destructive in conditions where temperatures are between 25 and $30{ }^{\circ} \mathrm{C}$ and relative humidity is high (Inoue-Nagata et al., 2016; Vale, Zambolim, Paul, \& Costa, 2000).
In Brazil, resistant cultivars to early blight are not commercially available, which makes the use of chemicals one of the main control methods (InoueNagata et al., 2016). Farmers adopt these techniques to mainly minimize the risk of financial losses, since sowing and managing a crop is very costly (Vale, Zambolim, Zambolim, \& Alvarenga, 2004).

The use of plant extracts and essential oils are alternatives for reducing the use of chemicals in agriculture as the intensive use of these pesticides causes environmental problems such as contamination of food, soil, and water; intoxication of people handling and exposed to these chemicals; selection of resistant phytopathogens; and elimination of beneficial microorganisms from the soil (Maia, Donato, \& Fraga, 2015).

Research has indicated the potential of crude extracts of essential oils obtained from medicinal plants in the control of phytopathogens, both due to 
their direct fungitoxic action and induced resistance. This finding suggests the presence of compounds that act as elicitors (Stangarlin, Kuhn, Assi, \& Schwan-Estrada, 2011a).

In this context, resistance induction mitigates the use of pesticides by activating defense mechanisms of plants against pathogens. Among these mechanisms is the activation of enzymes, such as peroxidase (POX), polyphenoloxidase (PPO), and phenylalanine ammonia-lyase (PAL) (Stangarlin et al., 2011b).

Essential oils have a complex chemical composition and can contain several substances such as terpenes and phenylpropanoids, which are considered biologically active compounds, mainly against microorganisms (Oliveira, Brugnera, Cardoso, Guimarães, \& Piccoli, 2011).

Commercially, bergamot (Citrus aurantium ssp. bergamia) is usually directed to fresh consumption, the juice industry, and extraction of the essential oil contained in its peel. Research has been conducted on the use of this essential oil as a potential antimicrobial agent (Pires \& Piccoli, 2012).

Essential oils extracted from plants of the genus Citrus have shown potential in the management of diseases due to their in vitro antifungal activity. Examples include the use of orange and mandarin essential oils against Botrytis cinerea isolated from strawberry (E. R. Lorenzetti et al., 2011), the use of Rangpur lime, West Indian lime, and Tahiti lime essential oils against Penicillium expansum (Pires \& Piccoli, 2012), and the reduction in the incidence of early blight in tomato fruits treated with bergamot essential oil (Ranieri et al., 2015).

This study aimed at evaluating the antifungal activity, the control of early blight, and the activation of the defense enzymes, peroxidase, polyphenoloxidase, and phenylalanine ammonialyase in tomato treated with bergamot essential oil and inoculated with $A$. solani.

\section{Material and Methods}

The pathogen Alternaria solani was indirectly isolated from a contaminated tomato fruit by cutting the fragments of the diseased tissue and depositing them in a Petri dish containing culture medium. It was kept at $25{ }^{\circ} \mathrm{C}$ in the dark. The isolate was preserved in a test tube with V8-agar culture medium using the Castellani method.

The bergamot essential oil was purchased from a prescription pharmacy in the city of Toledo (PR). The fungicide used in the experiment as standard treatment was azoxystrobin $\left(200 \mathrm{~g} \mathrm{~L}^{-1}\right)+$ difenoconazole $\left(125 \mathrm{~g} \mathrm{~L}^{-1}\right)$.

The completely randomized design was adopted for the in vitro experiment composed of seven treatments: $0 ; 500 ; 1000 ; 1500 ; 2000$, and 2500 $\mu \mathrm{L} \mathrm{L}^{-1}$ of essential oil, in addition to treatment with fungicide (azoxystrobin difenoconazole, $40 \mathrm{~mL} 100$ $\mathrm{L}^{-1}$ of water), with five replicates each.

The antifungal activity on the pathogen was evaluated using a mycelial growth and sporulation test. For that, the V8 juice agar culture medium was prepared and autoclaved (at $121{ }^{\circ} \mathrm{C}$ for $15 \mathrm{~min}$ ). When the medium was still melting, the mixture of essential oil and Tween 20 detergent was added in the proportion of $1: 1(\mathrm{v} / \mathrm{v})$ for homogenization of the solutions. The fungicide was also added to the culture medium after autoclaving.

After solidification of the culture medium, a 6-mm mycelial disc, which was removed from the edges of the colony at 14 days of age, was deposited in the center of each Petri dish (90 $\mathrm{mm}$ in diameter). These were then sealed with a plastic film and kept in a BOD chamber at $25^{\circ} \mathrm{C}$ in the dark.

The mycelial growth was evaluated daily by measuring the diameter of the colonies ( $\mathrm{mm}$ ) along two axes perpendicular to each other, starting 24 hours after the beginning of the experiment and lasting until a treatment reached the entire surface of the Petri dish. For determining the relationship 
between the days of evaluation and mycelial growth, measurements were made until all colonies covered the entire surface of the culture medium or did not show mycelial growth over the days.

After the evaluation of mycelial growth, the sporulation of the fungus was analyzed. For this, $10 \mathrm{~mL}$ of deionized water were added to each Petri dish, and after the colony was scraped using a glass slide, the suspension was filtered through gauze, and the number of spores per $\mathrm{mL}$ was counted in a Neubauer chamber. Sporulation was calculated based on the mycelial area of each treatment.

The in vivo experiment was conducted in a greenhouse located in Toledo (PR). A randomized block design was used, with the same treatments mentioned above and four replicates.

The soil was fertilized according to its chemical analysis and the necessities of the crop. Seeds of $S$. lycopersicum 'Odete', which are susceptible to $A$. solani, were sown in an expanded polystyrene tray with 200 cells containing commercial substrate. The seedlings were transplanted 30 days after sowing for soil cultivation and supplemented by fertigation.

After 30 days of transplanting, the second pairs of leaves were treated with the fungicide and the essential oil in the concentrations previously described. To obtain a homogeneous mixture between essential oil and water, Tween 20 was used in a $1: 1(\mathrm{v} / \mathrm{v})$ ratio.

Seventy-two hours after the application of treatments, the second pairs of leaves (treated) and the third pairs of leaves (untreated) were inoculated with $A$. solani. The spore suspension was prepared with the addition of $10 \mathrm{~mL}$ of deionized water in a Petri dish containing the pathogen grown for 30 days in a V8 juice agar culture medium. The suspension was filtered through gauze, and the concentration was determined in a Neubauer chamber, adjusting it to $1 \times 10^{4}$ spores $\mathrm{mL}^{-1}$. The suspension was applied to tomato leaves using a atomizer until reaching the point of drainage. The leaves were kept in a humid chamber for 12 hours in a plastic bag.
The severity of the early blight caused by $A$. solani was evaluated every two days, starting seven days after inoculation of the fungus, totaling five evaluations. Tomato leaves were photographed and analyzed using the Quant software (Vale, Fernandes, \& Liberato, 2003), which evaluated the severity of the disease. The area under the disease progression curve (AUDPC) was calculated using the trapezoidal integration method (Shaner \& Finney, 1977), which is based on the average disease severity per plant, the number of evaluations, and the interval between two evaluations. The following formula was used:

$$
\text { AUDPC }=\sum_{i=0}^{n}\left(\frac{Y_{i+n 1}+Y_{i}}{2}\right)\left(X_{i+1}-X_{i}\right)
$$

Where, $\mathrm{n}=$ number of evaluations; $\mathrm{Y}_{\mathrm{i}}=$ disease severity in the $i^{\text {th }}$ evaluation; $\mathrm{Xi}=$ time in days in the " $\mathrm{i}$ " -th evaluation.

For evaluating enzymatic activity, tomato seedlings were grown in a manner similar to the previous experiment, using a concentration of $2500 \mu \mathrm{L} \mathrm{L}^{-1}$ of essential oil. Thirty days after transplantation, 1-cm-diameter discs were collected from the plant tissue of treated leaves (second pair) and untreated leaves (third pair) at 0 (time of treatment), 24, 48, 72 (time of inoculation), 96, 120, and 144 hours after the treatments. The collections were also made in untreated plants that were only inoculated with the pathogen. A randomized block design was used with five replicates in a $7 \times 3$ factorial arrangement (seven collection times: 0, 24, 48, 72, 96, 120, and 144 hours, and three leaf conditions: second pair, third pair, and leaves of plants that were only inoculated). The collected samples were packed in aluminum foil envelopes and frozen at $-20{ }^{\circ} \mathrm{C}$ for subsequent biochemical analysis.

The leaf discs were mechanically homogenized in $4 \mathrm{~mL}$ of $0.01 \mathrm{M}$ sodium phosphate buffer $(\mathrm{pH}$ 6.0 ) in a porcelain mortar. The homogenate was centrifuged at $20000 \mathrm{~g}$ for $25 \mathrm{~min}$ at $4{ }^{\circ} \mathrm{C}$, and the supernatant that was obtained was considered as an enzymatic extract. 
Biochemical analyses were performed according to the methodology described by Hammerschmidt, Nucles and Kuc (1982) to analyze the peroxidase activity, the methodology described by Duangmal and Apenten (1999) to analyze polyphenoloxidase activity, and the methodology described by Umesha (2006) to determine the activity of the phenylalanine ammonia-lyase (PAL) enzyme. Protein content was determined according to the procedure described by Bradford (1976).

Data from in vitro and in vivo experiments were subjected to analysis of variance and, when significant, they were subjected to regression analysis at a $5 \%$ significance level. The fungicide was compared to the other treatments by the Dunnett test, using a 5\% significance level in the statistical software Genes (Cruz, 2006). The means of enzymatic activity were compared by the Tukey test at 5\% significance level. The data were analyzed using the statistical software Sisvar (Ferreira, 2011).

\section{Results and Discussion}

Mycelial growth showed a significant difference at the $5 \%$ significance level, with a dose-dependent effect for the concentrations of bergamot essential oil. A linear reduction was observed for the mycelial growth of $A$. solani, as can be seen in Figure 1.

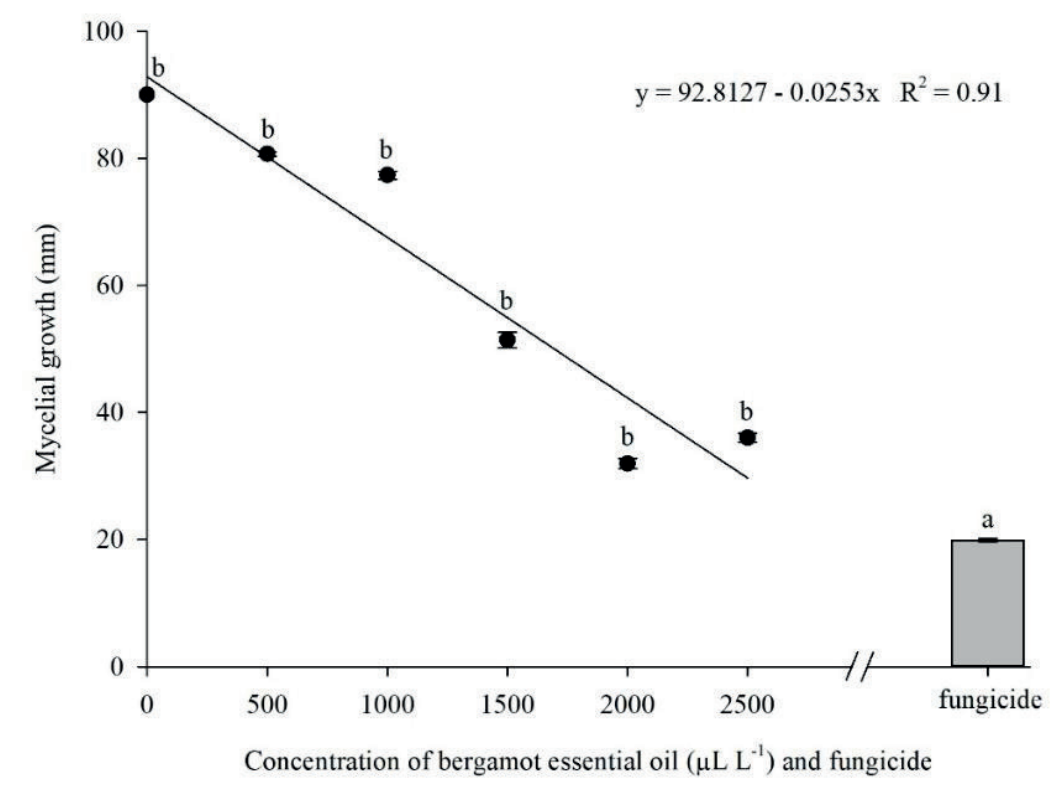

Figure 1. Mycelial growth (mm) of Alternaria solani in the presence of bergamot essential oil $\left(\mu \mathrm{L} \mathrm{L}^{-1}\right)$ and fungicide on the tenth day of evaluation. Note: different letters indicate a significant difference by Dunnett test. Bars indicate the standard error.

The concentration of $2500 \mu \mathrm{L} \mathrm{L}^{-1}$ inhibited $68.15 \%$ of the mycelial growth of the pathogen, which was the most effective concentration of bergamot essential oil in the experiment, followed by the doses of $2000 \mu \mathrm{L} \mathrm{L}^{-1}(54.52 \%), 1500 \mu \mathrm{L}$ $\mathrm{L}^{-1}(40.89 \%), 1000 \mu \mathrm{L} \mathrm{L}^{-1}(27.26 \%)$, and the concentration of $500 \mu \mathrm{L} \mathrm{L}^{-1}$, which inhibited the mycelial growth of $A$. solani by $13.63 \%$. Thus, the bergamot essential oil was effective in inhibiting the mycelial growth of the pathogen. The fungicide inhibited the pathogen by $78.57 \%$, being statistically superior to other treatments. 
The antifungal effect of the bergamot essential oil on A. solani can be explained by the sensitivity of the fungus when in contact with the active principles of the essential oil. Studies indicate that the main components of the bergamot essential oil are limonene and linalool (Tundis et al., 2012). These may be responsible for the inhibition of the pathogen.

The findings of the present study indicate that the mycelial growth of the analyzed pathogen can be inhibited by $100 \%$ when exposed to a concentration of $3668 \mu \mathrm{L} \mathrm{L}^{-1}$ of bergamot essential oil. However, this concentration is outside the range of concentrations analyzed in this study. These findings are consistent with Pires and Piccoli (2012). They found that essential oils of the genus Citrus (C. limonia, C. aurantifolia, and $C$. latifolia) have promising antifungal activity against Penicillium expansum at a concentration of $4000 \mu \mathrm{L}$ $\mathrm{L}^{-1}$, showing total inhibition of the mycelial growth of the pathogen, thus confirming the effectiveness of essential oils of the genus Citrus as antimicrobial agents.

The control of $A$. solani in tomato with essential oils has been studied by several authors. Cinnamon oil (Cinnamomum verum) at a concentration of $2000 \mu \mathrm{L} \mathrm{L}^{-1}$ inhibited $98.47 \%$ of the growth of the pathogen (Tomazoni, Giani, Ribeiro, Pauletti, \& Schwambach, 2013). Pinus elliottii $\left(1500 \mu \mathrm{L} \mathrm{L}^{-1}\right)$ and Pinus taeda $\left(5000 \mu \mathrm{L} \mathrm{L}^{-1}\right)$ oils inhibited the mycelial growth of $A$. solani by $14.31 \%$ and $19.51 \%$, respectively, on the fourteenth day of evaluation (Tomazoni, Pauletti, Ribeiro, \& Schwambach, 2014).
The daily mycelial growth of the pathogen as a function of the treatments can be seen in Figure 2. The concentrations of 1500,2000 , and $2500 \mu \mathrm{L} \mathrm{L}^{-1}$ of bergamot essential oil delayed mycelial growth. However, on the nineteenth day of evaluation, the pathogen reached growth similar to the concentration of $0 \mu \mathrm{L} \mathrm{L}^{-1}$. The fungicide prevented the mycelial growth of the pathogen, which showed no growth after the ninth day.

The essential oil at concentrations of 1500, 2000, and $2500 \mu \mathrm{L} \mathrm{L}^{-1}$ has higher amounts of components which may have slowed the growth of $A$. solani, since the growth of a pathogen is directly associated with the exposure conditions, and thus can be impaired or favored. It is suggested that successive applications of bergamot essential oil in the field can increase its effectiveness, potentially reducing the development of the mycelium of the pathogen, and consequently, mitigating its effects on tomato leaves.

The mycelial growth rate of Alternaria sp. and Alternaria carthami subjected to doses of candeia (Eremanthus erythropappus) and rosemary (Rosmarinus officinalis) essential oils were evaluated by Hillen et al. (2012). The authors observed that concentrations greater than $3000 \mu \mathrm{L}$ $\mathrm{L}^{-1}$ inhibit the mycelial growth of Alternaria sp. completely and that concentrations greater than $5000 \mu \mathrm{L} \mathrm{L}^{-1}$ resulted in the mycelial inhibition of $A$. carthami for both essential oils. 


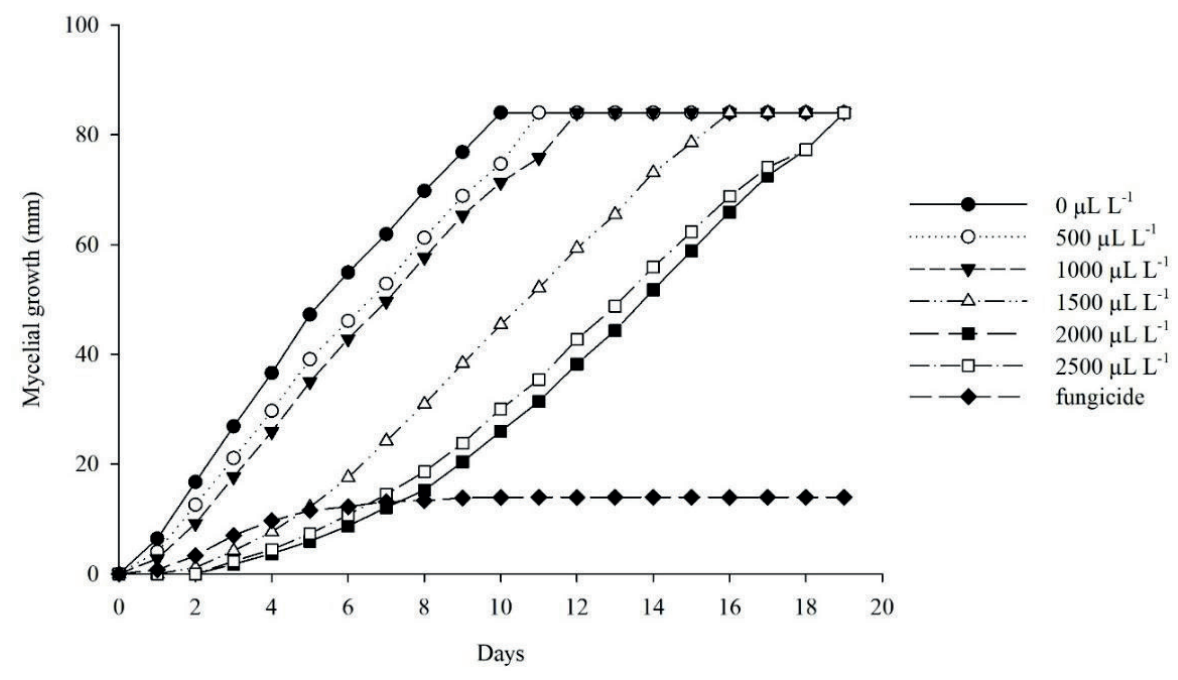

Figure 2. Mycelial growth (mm) of Alternaria solani according to the days of evaluation, subjected to doses of bergamot essential oil $\left(\mu \mathrm{L} \mathrm{L}^{-1}\right)$ and fungicide.

The mycelial growth rate of Botrytis cinerea isolated from strawberry subjected to concentrations of 125 and $1000 \mu \mathrm{L} \mathrm{L}^{-1}$ of orange and mandarin essential oils, both belonging to the genus Citrus, was evaluated by E. R. Lorenzetti et al. (2011). The authors observed that the essential oils showed little antifungal activity on the growth of the pathogen, and did not differ from the control. These results are similar to the present study, where the concentrations of 500 and $1000 \mu \mathrm{L} \mathrm{L}^{-1}$ showed mycelial growth similar to the concentration of $0 \mu \mathrm{L} \mathrm{L}^{-1}$.

After evaluating mycelial growth, the spores in each treatment were quantified, and the sporulation was determined considering the mycelial area. The sporulation showed quadratic behavior when subjected to increased concentrations of bergamot essential oil (Figure 3).

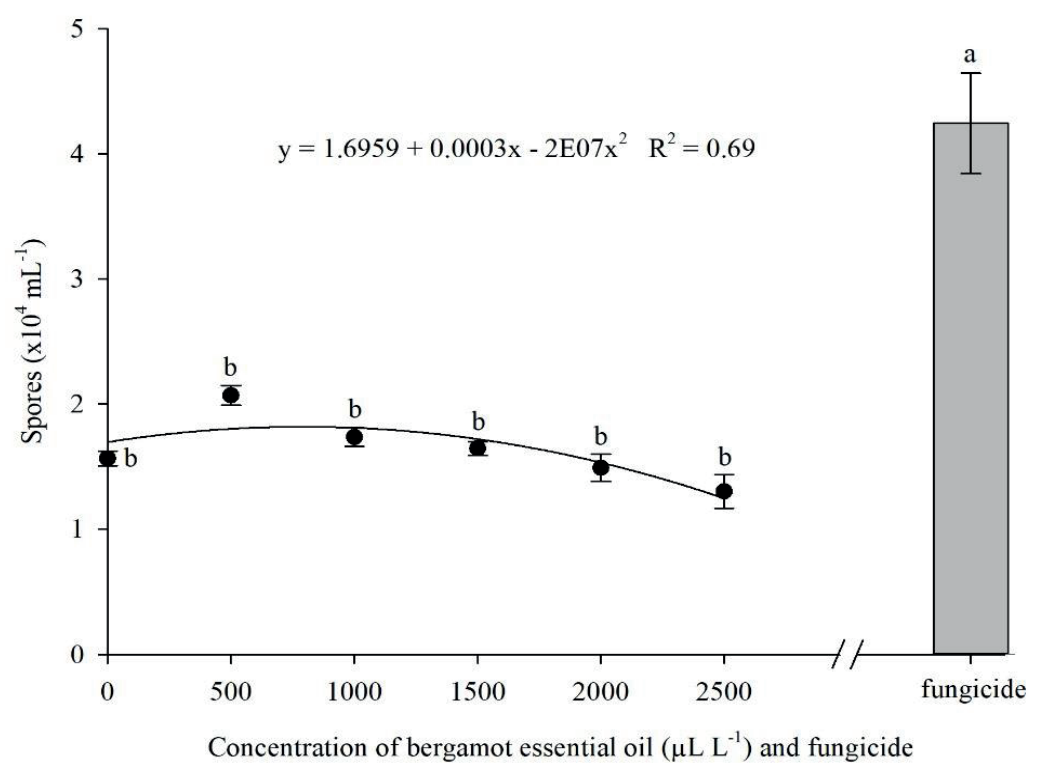

Figure 3. Sporulation of the fungus Alternaria solani subjected to concentrations of bergamot essential oil and fungicide. Note: different letters indicate a significant difference by Dunnett test. Bars indicate the standard error. 
The concentrations of 500 and $1000 \mu \mathrm{L} \mathrm{L}^{-1}$ of bergamot essential oil stimulated the sporulation of A. solani by $5.9 \%$. The concentration of 1500 $\mu \mathrm{L} \mathrm{L}^{-1}$ was similar to the concentration of $0 \mu \mathrm{L} \mathrm{L}^{-1}$. The decrease in sporulation was observed when the pathogen was subjected to concentrations of 2000 and $2500 \mu \mathrm{L} \mathrm{L}^{-1}$, reducing the production of reproductive structures by $11.79 \%$ and $29.48 \%$, respectively when compared to the concentration of $0 \mu \mathrm{L} \mathrm{L}^{-1}$.

Reducing the sporulation of $A$. solan $i$ in tomatoes using essential oil is beneficial for plants since it will result in lower amounts of propagules, which can cause epidemics in the environment.

The increase in concentrations was accompanied by an increase in the active ingredients in the essential oils, which in turn, may have impaired the sporulation of the pathogen. Rodrigues, Maffia, Dhingra and Mizubuti (2010) state that nutrition, temperature, light, and stress conditions can induce fungal sporulation.

The fungicide treatment resulted in an increase of spores by $150.18 \%$ compared to the concentration of $0 \mu \mathrm{L} \mathrm{L}^{-1}$. This may be directly associated with the stress that the pathogen was subjected to when its mycelial growth was interrupted, and as a measure of survival, it shows a greater number of reproductive structures.

E. R. Lorenzetti et al. (2011) evaluated the production of $B$. cinerea spores subjected to concentrations of 125 and $1000 \mu \mathrm{L} \mathrm{L}^{-1}$ of orange and mandarin essential oils, both belonging to the Citrus genus. No significant difference was observed between the concentrations of the treatment and control, which was also observed in the present study, where the reduction of sporulation was only found in higher concentrations, corresponding to 2000 and $2500 \mu \mathrm{L} \mathrm{L}^{-1}$.
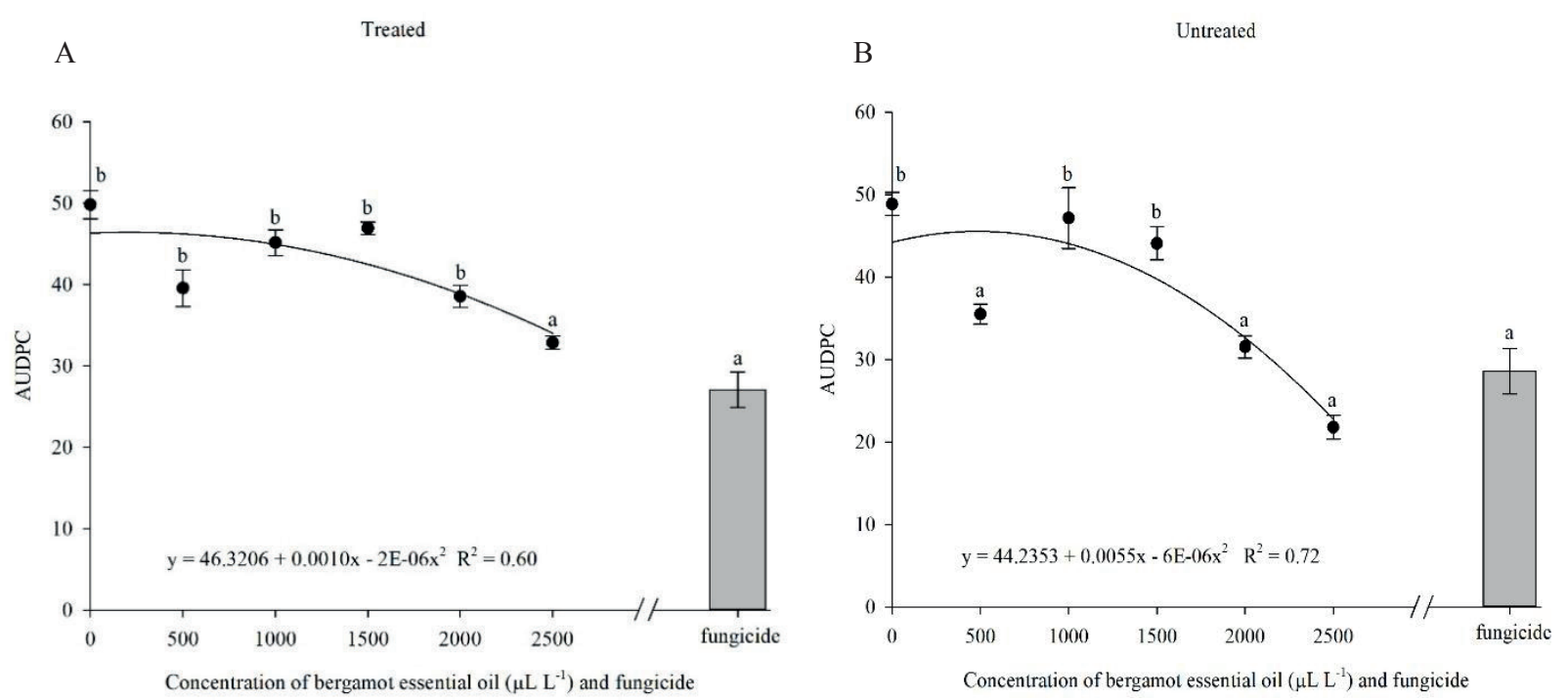

Figure 4. Area under the disease progress curve (AUDPC) in tomato leaves that were inoculated with Alternaria solani after being treated with bergamot essential oil and fungicide (A) and when they untreated (B). Note: different letters indicate a significant difference by Dunnett test. Bars indicate the standard error.

The final severity of the experiment reached 14\% in the control and $7.37 \%$ when treated with 2500 $\mu \mathrm{L} \mathrm{L}^{-1}$ of essential oil. The severity of the other treatments was between these values. In Figure 4, the quadratic response of the AUDPC can be seen in treated (A) and untreated (B) tomato leaves depending on the doses of bergamot essential oil. 
The concentration of $2500 \mu \mathrm{L} \mathrm{L}^{-1}$ of bergamot essential oil reduced AUDPC by $21.59 \%$ in the treated leaves. Similarly, the fungicide evaluated by the Dunnett test resulted in a $41.53 \%$ decrease. In leaves that did not receive the treatment directly (untreated), the fungicide reduced AUDPC by $35.32 \%$. Similarly, concentrations of $2500 \mu \mathrm{L} \mathrm{L}^{-1}$ reduced AUDPC by $53.69 \%$ and concentrations of $2000 \mu \mathrm{L} \mathrm{L}^{-1}$, reduced AUDPC by $29.39 \%$. The reduction in the incidence of the disease in untreated tomato leaves can be explained by the induction of systemic resistance, with the activation of defense enzymes.

A lower AUDPC is the result of a slow advance in the destruction of tomato leaves infected with A. solani. This delay caused by the action of the bergamot essential oil, both in local and systemic protection, allows plants to have a healthy leaf area for a longer time, preventing losses in the vegetative and reproductive development of the tomato crop, and even acting on leaves that were not treated.

The translocation of the active ingredient of the fungicide, azoxystrobin, in the tissues is classified as mesostemic, showing affinity with the leaf surface and being subject to absorption by the wax layer (G. J. Silva \& Behlau, 2018). Due to this feature, leaves not treated with fungicide showed similar AUDPC results as leaves that were treated. The action of the fungicide as a resistance inducer may have induced similar results in leaves that were treated and untreated with fungicide.

The number of early blight lesions of tomato on leaves treated and not treated with crude aqueous extract of camphor (Artemisia camphorata) and lemongrass (Cymbopogon citratus) was evaluated by Itako et al. (2008). The authors observed that the number of lesions did not differ statistically between treatments with extracts and the control, leading them to conclude that the extracts did not provide any local protection. However, a systemic effect was found as untreated leaves showed significant reductions in the number of early blight lesions. These results support those of the present study in confirming that compounds from medicinal plants can be used in the control of $A$. solani in tomato.

Direct antimicrobial activity and/or resistance induction in tomato leaves were also observed by Balbi-Peña et al. (2006) in the control of $A$. solani. The treatments with turmeric (Curcuma longa) at $1 \%$, curcumin $50 \mathrm{mg} \mathrm{L}^{-1}$, and copper oxychloride showed a better level of control compared to the control, but not superior to the fungicide azoxystrobin.

The physical and chemical changes in postharvest tomato fruits treated with compounds from medicinal plants were evaluated by Ranieri et al. (2015). These authors observed that the natural incidence of $A$. solani was reduced by up to $40 \%$ when the fruits were treated with bergamot essential oil at a concentration of $1000 \mu \mathrm{L} \mathrm{L}^{-1}$. This finding confirms its potential in reducing the incidence of the disease, as shown in the present study.

The enzymatic activity of POX in tomato leaves changed with the application of bergamot essential oil. At the 5\% confidence level, POX activity in tomato leaves was higher in the second and third pairs of leaves. This was not observed in the control, as shown in Figure 5.

The application of essential oil promoted an increase in POX activity in the second and third pairs of tomato leaves after 24 and 48 hours after treatment compared to the control. The activity on leaves from non-treated and inoculated plants did not show significant differences as a function of time. Subsequently, between 72 and 96 hours, which coincide with the inoculation of the pathogen, there was a significant increase in enzymatic activity in both leaves. However, this increase was not significant in the control. 


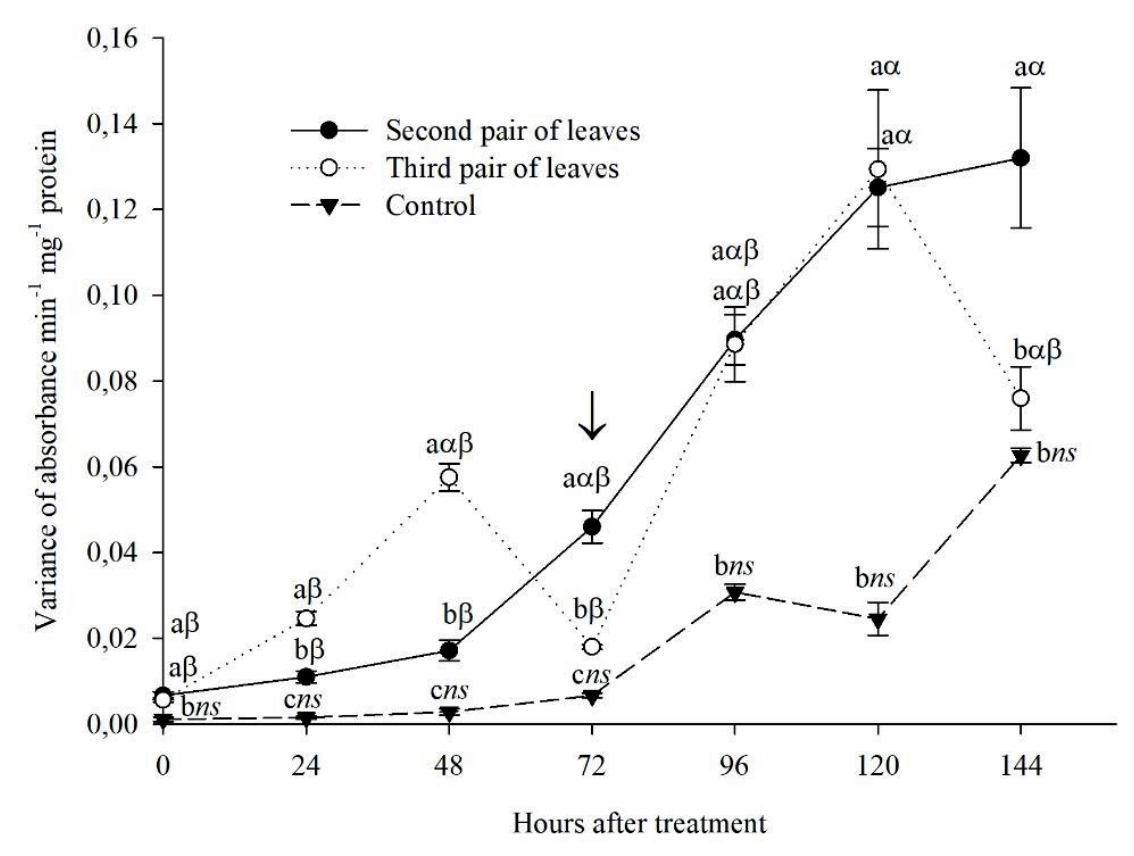

Figure 5. Peroxidase activity (POX) in tomato treated with $2500 \mu \mathrm{L} \mathrm{L}^{-1}$ of bergamot essential oil. The treatments were performed on the second pairs of leaves, 72 hours before the inoculation of Alternaria solani (time 0). Both the second and third pairs of leaves were inoculated with $A$. solani. The control corresponds to the non-treated plants inoculated with the pathogen. The arrow indicates inoculation with $A$. solani. Means followed by the same letter do not differ by Tukey test: Latin letters were used for comparison of treatment within each time; Greek letters were used for comparison between times within a treatment; ns: not significant. Bars indicate the standard error.

The enzymatic activity of POX in the second and third pairs of leaves was greater than the control at 96 and 120 hours, showing resistance induction. The peak of POX enzymatic activity in the second pair of leaves as a function of the collection times was observed at 120 and 144 hours, being significantly higher than the activity at 0,24 , and 48 hours. In the third pair of leaves, the greatest activity was at 120 hours, which was statistically different from the activity at 0,24 , and 72 hours.

According to Stangarlin et al. (2011b), POX activity changes the lignin production rate through the oxidation of phenolic alcohols, acting preventively by forming a physical barrier to infection and colonization by the pathogen. Consequently, it hinders the activities of the pathogen and its passage through the cell wall, providing more resistance against the diffusion of toxins released by the pathogen.

POX activity immediately after treatment, even if low, may be associated with a predisposition to resistance, greatly increasing with the arrival of the pathogen when the infectious process begins (Lorenzetti, Stangarlin, Kuhn, \& Portz, 2018).

Results similar to the present study were observed by R. F. Silva, Pascholati and Bedendo (2007) when they evaluated the resistance induction in tomato by aqueous extracts of mushrooms against bacterial wilt. The authors found a significant increase in POX in tomato leaves with inoculation of the pathogen, which occurred 72 hours after treatment.

Araujo and Menezes (2009) observed an increase in POX activity in tomatoes caused by 
treatment with Bacillus subtilis and acibenzolarS-methyl (ASM). Thus, although both biotic and abiotic agents can promote POX activity, studies on the activation of plant defense enzymes with the use of bergamot essential oil are still scarce.
PPO activity in tomato leaves showed a significant difference when treated with bergamot essential oil, with a peak activity being observed only in the second pair of tomato leaves 96 hours after treatment, with an increase of $175.61 \%$ in the enzymatic activity (Figure 6).

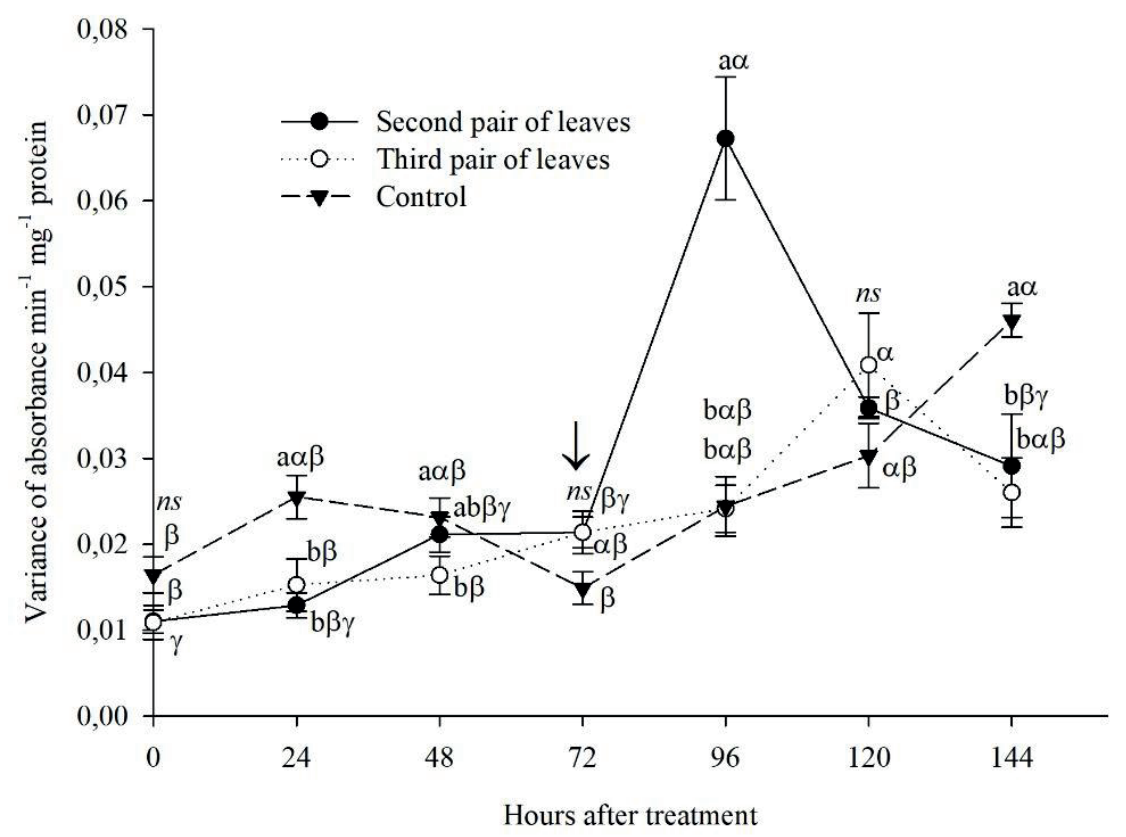

Figure 6. Polyphenoloxidase (PPO) activity in tomato treated with $2500 \mu \mathrm{L}$ $\mathrm{L}^{-1}$ of bergamot essential oil. The treatments were performed on the second pair of leaves, 72 hours before the inoculation of Alternaria solani (time 0). Both the second and third pairs of leaves were inoculated with $A$. solani. The control corresponds to the non-treated plants inoculated with the pathogen. The arrow indicates inoculation with $A$. solani. Mean followed by the same letter do not differ by Tukey test: Latin letters were used for comparison of treatment within each time; Greek letters were used for comparison between times within a treatment; $n s$ : not significant. Bars indicate the standard error.

Variations in the PPO activity as a function of collection times were observed in all leaf conditions. In the second pairs of leaves, the peak activity was in the collection made at 96 hours. In the third pairs of leaves, the highest activity was observed at 120 hours, which was statistically different from the activity at 48,24, and 0 hours. In the leaves of plants that were not treated, but were inoculated with the pathogen (control), there is a significant increase in PPO activity only at 144 hours compared to the activity at the time of the inoculation of the pathogen (72 hours). The application of bergamot essential oil reduced PPO activity in the second and third pairs of tomato leaves compared to the control after 24 hours of treatment. This result agrees with R. F. Silva et al. (2007) who found a decrease in the first hours of evaluation of PPO activity in tomato plants treated with an abiotic inducer and inoculated with Ralstonia solanacearum. 
However, at 96 hours, an increase in enzyme activity was observed in the second pairs of leaves, due to the infectious process and the resistance induction process of the essential oil, with a local effect. According to Portz et al. (2011), the colonization of the pathogen causes a high enzymatic activity due to the defense mechanisms that are activated more strongly after inoculation.

PPO is an oxidative enzyme that participates in the plant defense reaction against phytopathogens, acting on the oxidation of phenolic compounds, transforming them into quinines, which are highly toxic to microorganisms (Stangarlin et al., 2011b). The present study shows that the increase in this enzyme usually occurs in the infected tissues (Agrios, 2005).

The activity of PAL in the second and third pair of leaves and the control can be seen in Figure 7.

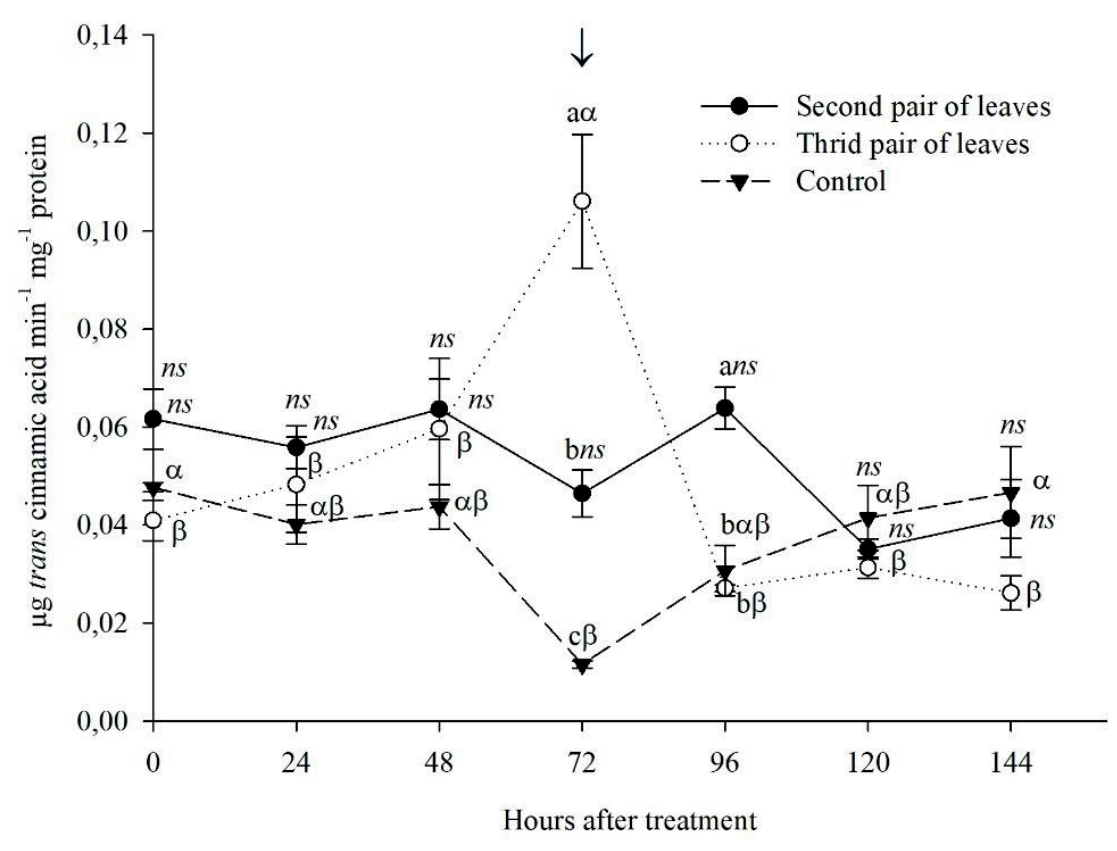

Figure 7. Phenylalanine ammonia-lyase (PAL) activity in tomato treated with $2500 \mu \mathrm{L} \mathrm{L}^{-1}$ of bergamot essential oil. The treatments were performed on the second pairs of leaves, 72 hours before the inoculation of Alternaria solani (time 0 ). Both the second and third pairs of leaves were inoculated with $A$. solani. The control corresponds to the non-treated plants inoculated with the pathogen. The arrow indicates the inoculation with A. solani. Mean followed by the same letter do not differ by Tukey test: Latin letters were used for comparison of treatment within each time; Greek letters were used for comparison between times within a treatment; $n s$ : not significant. Bars indicate the standard error.

The application of bergamot essential oil did not change the enzymatic activity of PAL in the evaluations at 24 and 48 hours. The inoculation of the pathogen resulted in a higher increase in PAL activity for the third pairs of leaves compared to the control and the second pairs of leaves.

At 96 hours, PAL activity was higher in the second pair of leaves, which were treated and inoculated. An 
increase of approximately $108 \%$ in the enzymatic activity was observed compared to the third pairs of leaves and the control. Subsequently, at 120 and 144 hours, both leaves showed no difference compared to the control, showing little effectiveness of the bergamot essential oil in the activation of the PAL enzyme.

PAL is an enzyme of high importance in the metabolic reactions of phenolic compounds, being responsible for the deamination of L-phenylalanine, transforming it into trans-cinnamic acid and ammonia, and triggering metabolic reactions that generate phenylpropanoid products, including lignin (Stangarlin et al., 2011b).

R. F. Silva et al. (2007) analyzed the activity of PAL in tomato leaves treated with ASM and aqueous mushroom extract, which were inoculated with $R$. solanacearum. The authors observed a decrease in enzyme activity in plants treated with inducers and inoculated with the bacteria, which indicates that the PAL activity depends on the pathosystem.

Bergamot essential oil, at a dose of $2500 \mu \mathrm{L} \mathrm{L}^{-1}$, showed antifungal activity against $A$. solani and was able to control the black spot of tomato, which may have occurred both by direct antimicrobial activity and by induction of resistance involving the peroxidase enzymes, polyphenoloxidase, and phenylalanine ammonia-lyase.

\section{References}

Agrios, G. N. (2005). Plant pathology (5nd ed.). Amsterdam: Elsevier Academic Press.

Araujo, F. F., \& Menezes, D. (2009). Indução de resistência a doenças foliares em tomateiro por indutores biótico (Bacillus subtilis) e abiótico (Acibenzolar-S-Metil). Summa Phytopathologica, 35(3), 169-172. doi: 10.1590/S0100-54052009000300001

Balbi-Peña, M. I., Becker, A., Stangarlin, J. R., Franzener, G., Lopes, M. C., \& Schwan-Estrada, K. R. F. (2006). Controle de Alternaria solani em tomateiro por extratos de Curcuma longa e Curcumina - II. Avaliação in vivo. Fitopatologia Brasileira, 31(4), 401-404. doi: 10.1590/S0100-41582006000400012
Bradford, M. M. (1976). A rapid and sensitive method for the quantitation of microgram quantities of protein utilizing the principle of protein-dye binding. Analytical Biochemistry, 72, 248-254. doi: 10.1016/0003-2697(76)90527-3

Cruz, C. D. (2006). Programa Genes: estatística experimental e matrizes. Viçosa, MG: UFV.

Duangmal, K., \& Apenten, R. K. O. (1999). A comparative study of polyphenoloxidases from taro (Colocasia esculenta) and potato (Solanum tuberosum var. Romano). Food Chemistry, 64, 351359. doi: 10.1016/S0308-8146(98)00127-7

Ferreira,D.F.(2011). Sisvar: a computer statistical analysis system. Ciência e Agrotecnologia, 35(6), 1039-1042. doi: 10.1590/S1413-70542011000600001

Filgueira, F. A. R. (2008). Novo manual de olericultura: agrotecnologia moderna na produção e na comercialização de hortaliças (3a ed.). Viçosa, MG: UFV.

Hammerschmidt, T. R., Nucles, E. M., \& Kuc, J. (1982). Association of enhanced peroxidase activity with induced systemic resistance of cucumber to Colletotrichum lagenarium. Physiological Plant Pathology, 20, 73-82. doi: 10.1016/00484059(82)90025-X

Hillen, T., Schwan-Estrada, K. R. F., Mesquini, R. M., Cruz, M. E. S., Stangarlin, J. R., \& Nozaki, M. (2012). Atividade antimicrobiana de óleos essenciais no controle de alguns fitopatógenos fúngicos in vitro e no tratamento de sementes. Revista Brasileira de Plantas Medicinais, 14(3), 439-445. doi: 10.1590/ S1516-05722012000300003

Instituto Capixaba de Pesquisa, Assistência Técnica e Extensão Rural (2010). Tomate. Vitória: Incaper.

Inoue-Nagata, A. K., Lopes, C. A., Reis, A., Pereira, R. B., Quezado-Duval, A. M., Pinheiro, J. B., \& Lima, M. F. (2016). Doenças do Tomateiro. In L Amorim, J. A. M.,Rezende, A. Bergamin, Fo, \& L. E. A. Camargo (Eds.), Manual de fitopatologia: doenças das plantas cultivadas (pp. 697-735). Ouro Fino: Agronômica Ceres.

Itako, A. T., Schwan-Estrada, K. R. F., Tolentino, J. B., Jr., Stangarlin, J. R., \& Cruz, M. E. S. (2008). Atividade antifúngica e proteção do tomateiro por extratos de plantas medicinais. Tropical Plant Pathology, 33(3), 241-244. doi: 10.1590/S1982-56762008000300011

Lorenzetti, E., Stangarlin, J. R., Kuhn, O. J., \& Portz, R. L. (2018). Indução de resistência à Macrophomina phaseolina em soja tratada com extrato de alecrim. Summa Phytopathologica, 44(1), 45-50. doi: 10. 1590/0100-5405/176895 
Lorenzetti, E. R., Monteiro, F. P., Souza, P. E., Souza, R. J., Scalice, H. K., Diogo, R., Jr., \& Pires, M. S. O. (2011). Bioatividade de óleos essenciais no controle de Botrytis cinerea isolado de morangueiro. Revista Brasileira de Plantas Medicinais, 13(especial), 619627. doi: 10.1590/S1516-05722011000500019

Maia, T. F., Donato, A., \& Fraga, M. E. (2015). Atividade antifúngica de óleos essenciais de plantas. Revista Brasileira de Produtos Agroindustriais, 17(1), 105-116.

Oliveira, M. M. M., Brugnera, D. F., Cardoso, M. G., Guimarães, L. G. L., \& Piccoli, R. H. (2011). Rendimento, composição química e atividade antilisterial de óleos essenciais de espécies de Cymbopogon. Revista Brasileira de Plantas Medicinais, 13(1), 8-16. doi: 10.1590/S151605722011000100002

Pires, T. C., \& Piccoli, R. H. (2012). Efeito inibitório de óleos essenciais do gênero Citrus sobre o crescimento de micro-organismos. Revista Instituto Adolfo Lutz, 71(2), 378-385.

Portz, R. L., Fleischmann, F., Koehl, J., Fromm, J., Ernst, D., Pascholati, S. F., \& Osswald, W. F. (2011). Histological, physiological and molecular investigations of Fagus sylvatica seedlings infected with Phytophthora citricola. Forest Pathology, 41(3), 202-211. doi: 10.1111/j.1439-0329.2010.00667.x

Ranieri, E., Schwan-Estrada, K. R. F., Oliveira, J. S. B., Mesquini, R. M., Clemente, E., \& Cruz, M. E. S. (2015). Utilização de compostos bioativos de plantas medicinais na pós-colheita de tomate. Revista Scientia Agraria Paranaensis, 14(3), 160-165. doi: 10.1818/sap.v14i3.9111

Rodrigues, T. T. M. S., Maffia, L. A., Dhingra, O. D., \& Mizubuti, E. S. G. (2010). In vitro production of conidia of Alternaria solani. Tropical Plant Pathology, 35(4), 203-212. doi: 10.1590/S198256762010000400001

Shaner, G., \& Finney, R. E. (1977). The effect of nitrogen fertilization on the expression of slow-mildewing resistance in knox wheat. Phytopathology, 67, 10511056. doi: 10.1094/Phyto-67-1051

Silva, G. J., Jr., \& Behlau, F. (2018). Controle químico. In L. Amorim, J. A. M. Rezende, \& A, Bergamin, Fo . (Eds.), Manual de fitopatologia: princípios e conceitos (pp. 239-260). Ouro Fino: Agronômica Ceres.

Silva, R. F., Pascholati, S. F., \& Bedendo, I. P. (2007). Indução de resistência em tomateiro por extratos aquosos de Lentinula edodes e Agaricus blazei contra Ralstonia solanacearum. Fitopatologia Brasileira, 32(3), 189-196. doi: 10.1590/S010041582007000300002
Stangarlin, J. R., Kuhn, O. J., Assi, L., \& SchwanEstrada, K. R. F. (2011a). Control of plant diseases using extracts from medicinal plants and fungi. In A. Méndez-Vilas (Ed.), Science against microbial pathogens: communicating current research and technological advances (pp. 1033-1042). Badajoz: Formatex Research Center.

Stangarlin, J. R., Kuhn, O. J., Toledo, M. V., Portz, R. L., Schwan-Estrada, K. R. F., \& Pascholati, S. F. (2011b). A defesa vegetal contra fitopatógenos. Scientia Agrária Paranaensis, 10(1), 18-46. doi: 10. 1818/sap.v10i1.5268

Tomazoni, E. Z., Giani, S. G., Ribeiro, R. T. S., Pauletti, G. F., \& Schwambach, J. (2013). Atividade antifúngica do óleo essencial de Cinnamomum zeylanicum Ness sobre fungos fitopatogênicos do tomateiro (Lycopersicon esculentum Mill.). Cadernos de Agroecologia, 8(2), 1-5, 2013.

Tomazoni, E. Z., Pauletti, G. F., Ribeiro, R. T. S., \& Schwambach, J. (2014). Atividade antifúngica in vitro dos óleos essenciais de Pinus elliottii e Pinus taeda sobre o fungo patógeno de tomateiro Alternaria solani sorauer. Caderno Pedagógico, 11(1), 68-77.

Tundis, R., Loizzo, M. R., Bonesi, M., Menichini, F., Mastellone, V., Colica, C., \& Menichini, F. (2012). Comparative study on the antioxidant capacity and cholinesterase inhibitory activity of Citrus aurantifolia Swingle, C. aurantium L., and $C$. bergamia Risso and Poit. peel essential oils. Journal of Food Science, 71(1), 40-46. doi: 10.1111/j.17503841.2011.02511.x

Umesha, S. (2006). Phenylalanine ammonia lyase activity in tomato seedlings and its relationship to bacterial canker disease resistance. Phytoparasitica, 34(1), 68-71. doi: 10.1007/BF02981341

Vale, F. X. R., Zambolim, L., Zambolim, E. M., \& Alvarenga, M. A. R. (2004). Manejo Integrado das doenças do tomateiro: epidemiologia e controle. In M. A. R. Alvarenga (Ed.), Tomate: produção em campo, em casa de vegetação e em hidroponia (pp. 217). Lavras: UFLA.

Vale, F. X. R., Fernandes, E. I. F., Fo., \& Liberato, J. R. (2003) Quant: a software for plant disease severity assessment. Proceedings of the 8th International Congress of Plant Pathology, Christchurch, New Zealand, pp.105.

Vale, F. X. R., Zambolim, L., Paul, P. A., \& Costa, H. (2000). Doenças causadas por fungos em tomate. In Zambolim, L., Vale, F. X. R. \& Costa, H., Controle de doenças de plantas: hortaliças (pp. 699-756). Viçosa, MG: UFV. 